Received: 29 Oktober 2021

Revised: 14 Desember 2021

Accepted: 30 Desember 2021

Published: 31 Desember 2021

\title{
Aplikasi Metode K-Medoid pada Pengelompokan Kabupaten/Kota di Jawa Barat Berdasarkan Indikator Indeks Pembangunan Manusia Tahun 2020
}

\author{
Ridhwan Mustajab $^{1, \mathrm{a})}$, Rafika Aristawidya ${ }^{1, \mathrm{~b})}$, Lintang Puspita ${ }^{1, \mathrm{c})}$, Edy Widodo ${ }^{1, \mathrm{~d}}$ \\ ${ }^{1}$ Departemen Matematika dan Ilmu Pengetahuan Alam, Universitas Islam Indonesia, Sleman \\ Email: $18611009 @$ students.uii.ac.id, ${ }^{\text {b) }}$ 18611050@ @ students.uii.ac.id, ${ }^{c}$ 18611088@ @ students.uii.ac.id, \\ d)edywidodo@uii.ac.id
}

\begin{abstract}
Humans have more choices to fulfill their economic, social, and cultural needs in their lives. The development of West Java is not only focused on equity, but also emphasizes the process of development and change, and emphasizes the acceleration of growth and equitable development of West Java. Therefore, it is important to consider the use of the Human Development Index (HDI) to classify regions/cities in West Java. This method uses K-Medoids clustering, which takes objects to represent the cluster center of each cluster. The advantage of the K-Medoids algorithm is that it is not sensitive to outliers, so objects that have more value can be stored in the data distribution. The results obtained by grouping with K-medoids clustering result in cluster 1 of 14 members as districts/cities with low HDI numbers. Cluster 2 consists of 9 members as districts/cities with a moderate number of HDI. While cluster 3 has 4 members as districts/cities with high HDI numbers.
\end{abstract}

Keywords: K-Medoids, HDI, West Java, Cluster, Indicators.

\begin{abstract}
Abstrak
Masyarakat memiliki lebih banyak pilihan dalam memenuhi kebutuhan ekonomi, sosial dan budaya. Pembangunan Jawa Barat bukan hanya terpusat pada pemerataan, tetapi juga menekankan pada proses pembangunan dan perubahan, serta menekankan pada percepatan pertumbuhan dan pemerataan pembangunan Jawa Barat. Oleh karena itu, penting sebagai pertimbangan penggunaan Indeks Pembangunan Manusia (IPM) untuk mengelompokkan daerah/kota Jawa Barat. Metode kali ini menggunakan clustering $K$-Medoids, yang mengambil objek untuk perwakilan pusat cluster dari setiap cluster. Kelebihan dari algoritma K-Medoids adalah tidak sensitif kepada pencilan, sehingga objek yang mempunnyai nilai lebih dapat disimpan dalam distribusi data. Didapatkan pengelompokan dengan $K$ medoids clustering diperoleh hasil cluster 1 sebanyak 14 anggota sebagai kabupaten/kota dengan jumlah IPM yang rendah. Cluster 2 sebanyak 9 anggota sebagai kabupaten/kota dengan jumlah IPM yang sedang. Sedangkan cluster 3 sebanyak 4 anggota sebagai kabupaten/kota dengan jumlah IPM yang tinggi.
\end{abstract}

Kata Kunci: K-Medoid, IPM, Jawa Barat, Cluster, Indikator. 


\section{PENDAHULUAN}

Program Pembangunan PBB menunjukkan bahwa pembangunan manusia adalah proses peningkatan pilihan manusia (UNDP, 2001). Manusia memiliki lebih banyak kesempatan untuk memenuhi kebutuhannya. Sesuai dengan Provinsi Jawa Barat (Sutjipto, 2006), visinya adalah melakukan akselerasi pembangunan dalam rangka peningkatan kesejahterahan penduduk. Pendekatan pembangunan wilayah Jawa Barat tidak hanya fokus pada aspek pertumbuhan, namun ditambah menekankan proses pembangunan yang menghambat percepatan pertumbuhan dan pemerataan pembangunan Jawa Barat.

Provinsi Jawa Barat terus berkembang antara tahun 2010 hingga 2020. Indeks Pembangunan Manusia (IPM) Jawa Barat pada tahun 2010 yaitu 66.15 dan meningkat menjadi 72.09 pada 2020 . Selama periode tersebut, Indeks Pembangunan Manusia Provinsi Jawa Barat rata-rata meningkat $0.86 \%$ per tahun. Laju pertumbuhan paling lambat terjadi pada tahun 2020. IPM Provinsi Jawa Barat hanya meningkat sebesar $0.08 \%$ dibandingkan dengan tahun 2019, namun lebih cepat dari laju pertumbuhan IPM nasional pada tahun 2020. Pada tahun 2020, IPM Indonesia akan mencapai 71.94, meningkat $0.03 \%$ dibandingkan tahun sebelumnya (BPS, 2021).

Banyak kajian tentang IPM, antara lain (Widodo, Mashita \& Prasetyowati, 2020) yang berhasil membandingkan metode Average Linkage, Complete Linkage, dan Ward's yang digunakan mengelompokkan daerah/kota Jawa Tengah terpacu pada indikator IPM. Berdasarkan ketiga metode hirarki clustering yang digunakan, metode pengelompokan yang paling baik adalah metode average linkage. Berdasarkan metode average linkage, anggota kelompok ditentukan sebagai berikut: kelompok 1 memiliki 20 anggota, kelompok 2 memiliki anggota, dan kelompok 3 memiliki 3 anggota.

Penelitian berikutnya yaitu (Dewi \& Sutrisna, 2014) yang meneliti tentang pengaruh komponen indeks pembangunan manusia terhadap pertumbuhan ekonomi Provinsi Bali. Indeks kesehatan, pendidikan, dan daya beli berpengaruh signifikan terhadap pertumbuhan ekonomi Bali. Dinyatakan bahwa semakin baik kualitas sumber daya manusia terkait dengan indeks pembangunan manusia, maka semakin dapat dicapai dan mendorong pertumbuhan ekonomi sebagai modal pembangunan ekonomi. Dalam beberapa kasus, indeks kesehatan tidak berpengaruh pada dampak komponen indeks pembangunan manusia terhadap pertumbuhan ekonomi Bali. Indeks pendidikan dan indeks daya beli memiliki dampak positif yang signifikan terhadap pertumbuhan ekonomi Bali. Sementara itu masih sedikit yang membahas tentang IPM di Jawa Barat. Dengan demikian peneliti tertarik melakukan penelitian menggunakan clustering K-Medoid. Metode ini dapat digunakan untuk mengatasi kelemahan dari algoritma K-Means yang sangat sensitif terhadap outlier dikarenakan objek ini memiliki jarak yang jauh dari sebagian besar data lainnya, dengan demikian jika dimasukkan ke dalam suatu cluster data semacam ini dapat mendistorsi nilai rata-rata cluster tersebut (Wira, Budianto, \& Wiguna, 2019).

Keuntungan lain dari metode ini adalah hasil dari proses pengelompokan tidak selalu cocok dengan kumpulan data (Riyanto, 2019). Oleh karena itu, tujuan penelitian ini diantaranya:

1) Mengetahui gambaran umum indikator IPM berdasarkan kabupaten/kota di Provinsi Jawa Barat

2) Mengetahui hasil pengelompokan kabupaten/kota di Provinsi Jawa Barat berdasarkan indikator IPM

3) Mengetahui karakteristik dari setiap kabupaten/kota di Provinsi Jawa Barat berdasarkan indikator IPM.

\section{METODOLOGI}

\section{Bahan dan Data}

Pada penelitian kali ini menggunakan data sekunder yang bersumber dari Badan Pusat Statistik, dengan variabel yang digunakan diantaranya: Indikator Angka Harapan Hidup (AHH), Indikator Ratarata Lama Sekolah (RRLS), Indikator Harapan Lama Sekolah (HLS), dan Indikator Pengeluaran Per Kapita Disesuaikan (PP). Seluruh indikator yang digunakan merupakan variabel independen pada 
tahun 2020. Unsur tersebut tidak berdiri sendiri, melainkan saling memengaruhi satu dengan yang lainnya (Dinas Perhubungan, 2013).

\section{Metode Penelitian}

Analisis kelompok adalah pengaplikasian suatu teknik untuk mengklasifikasikan objek ke sebuah kelompok-kelompok yang relatif sama atau homogen, yang dikenal dengan klasterisasi. Kasus atau objek pada masing-masing cluster mirip (sama) antara satu dengan yang lain serta tidak memiliki kemiripan (berbeda) dengan objek pada cluster lain. Analisis kelompok yang digunakan penelitian ini ialah cluster non hirarki metode K-Medoid dengan menggunakan jarak Euclidean (Supranto, 2004). Jarak Euclid dapat digunakan ketika setiap variabel yang digunakan saling ortogonal atau tidak berkorelasi, dan memiliki satuan serta skala pengukuran sama (Asroni \& Adrian, 2015). Jarak euclid objek $x^{\prime}=\left[x_{1}, x_{2}, \ldots, x_{p}\right]$ dan $y^{\prime}=\left[y_{1}, y_{2}, \ldots, y_{p}\right]$ berdimensi $p$, ditulskan pada persamaan (1) di bawah ini.

$$
\begin{aligned}
d(x, y) & =\sqrt{\left(x_{1}-y_{1}\right)^{2}+\left(x_{2}-y_{2}\right)^{2}+\cdots+\left(x_{p}-y_{p}\right)^{2}} \\
& =\sqrt{\sum_{i=1}^{p}\left(x_{i}-y_{i}\right)^{2}}
\end{aligned}
$$

Algoritma K-Medoids disebut partisi di sekitar medoid. Pada metode partisi, data yang terdiri dari $n$ objek dibagi menjadi $k$ kelompok dengan jumlah $k \leq n$. Pembentukan kelompok untuk mengoptimalkan kriteria isolasi objektif sesuai dengan kedekatan jarak setiap objek. Medoid merupakan objek yang dianggap mewakili grup dan pusat grup. Algoritma k-medoids menggunakan objek dalam kumpulan objek yang mewakili grup. Kelompok ini dibentuk dengan menghitung jarak antara titik pusat dan objek non titik pusat. Analisis ini menggunakan nilai absolute error (E) untuk meminimalkan ketidaksetaraan untuk setiap objek dalam cluster (Han \& Kamber, 2006).

$$
E=\sum_{c-1}^{k} \sum_{i=1}^{n_{c}}\left|P_{i c}-O_{c}\right|
$$

Keterangan:

$n_{c}=$ Jumlah obyek dalam cluster ke- $c$

$P_{i c}=$ Obyek non-mdoids $i$ dalam cluster ke- $c$

$O_{c}=$ Nilai medoids di cluster ke-c

Pada metode $k$-medoid ini, medoid awal adalah $k$ objek yang dipilih secara acak, kemudian objek non-medoid yang mirip dengan medoid tersebut dikelompokkan sehingga menjadi satu. Apabila harapannya untuk mendapatkan kualitas cluster yang baik, maka proses substitusi objek medoid dengan non-medoid dilakukan melalui proses iteratif. Kualitas ini dapat dihitung dengan menggunakan nilai absolute error (E) baik sebelum maupun sesudah proses penggantian sampai $O_{c}$ tidak berubah. Adapun langkah-langkah yang peneliti lakukan dalam menyelesaikan studi kasus ini. 


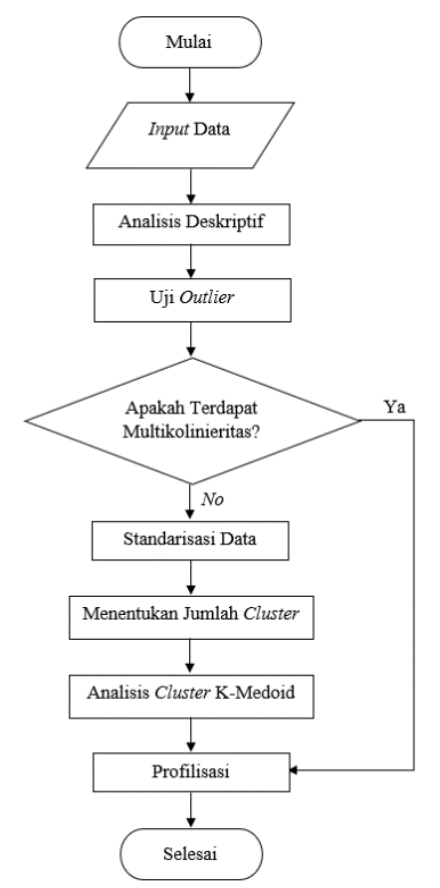

GAMBAR 1. Diagram Alir Penelitian

1. Input variabel yang akan dianalisis, diantaranya: AHH, RRLS, HLS, dan PP.

2. Melakukan analisis deskriptif untuk mengetahui suatu gambaran umum setiap variabel.

3. Melakukan pengujian apakah terdapat outlier pada data yang akan dianalisis.

4. Melakukan uji non multikolinieritas yang merupakan asumsi untuk penelitian ini dapat dilanjutkan dengan menggunakan analisis cluster.

5. Melakukan standarisasi data dikarenakan terdapat perbedaan variansi yang cukup jauh.

6. Menentukan jumlah cluster menggunakan metode silhouette.

7. Melakukan clustering dengan menggunakan metode K-Medoid.

8. Profilisasi dengan pemetaan dari hasil cluster Kabupaten/Kota di Provinsi Jawa Barat berdasarkan indikator IPM tahun 2020.

\section{HASIL DAN PEMBAHASAN}

\section{Statistika Deskriptif}

Statistika deskriptif dapat diaplikasikan untuk memberikan suatu gambaran umum terhadap data dengan variabel yang digunakan yaitu data IPM Provinsi Jawa Barat yang terdiri dari variabel AHH, RRLS, HLS, dan PP dengan melihat dari nilai mean atau rata-rata, nilai minimum, serta nilai maksimum. Berikut analisis deskriptif yang diperoleh, dapat dilihat pada TABEL 1.

TABEL 1. Statistika Deskriptif

\begin{tabular}{lcccc}
\hline \multicolumn{1}{c}{ Hasil } & \multicolumn{4}{c}{ Variabel } \\
\hline & AHH & RRLS & HLS & PP \\
\hline Min. & 69.47 & 6.300 & 11.70 & 7851 \\
Mean & 72.24 & 8.541 & 12.79 & 10717 \\
Max. & 75.01 & 11.280 & 14.20 & 16887 \\
\hline
\end{tabular}

Berdasarkan TABEL 1 diketahui hasil analisis deskriptif dari variabel AHH memiliki nilai minimum dan maksimum sebesar 69.47 tahun dan 75.01 tahun, serta nilai rata-rata sebesar 72.24 tahun. Variabel kedua yakni RRLS memiliki nilai minimum dan maksimum sebesar 6.300 tahun dan 11.280 tahun serta nilai rata-rata sebesar 8.541 tahun. Variabel ketiga yaitu variabel HLS memiliki 
nilai minimum dan maksimum sebesar 11.70 tahun dan 14.20 tahun, serta nilai rata-rata 12.79 tahun. Variabel keempat yaitu variabel PP memiliki nilai minimum dan maksimum sebesar 7852 ribu dan 16887 ribu, serta nilai rata-rata sebesar 10717 ribu.

\section{Uji Data Outlier}

Data outlier merupakan data yang sering disebut sebagai data pencilan. Berikut tampilan output yang dihasilkan.

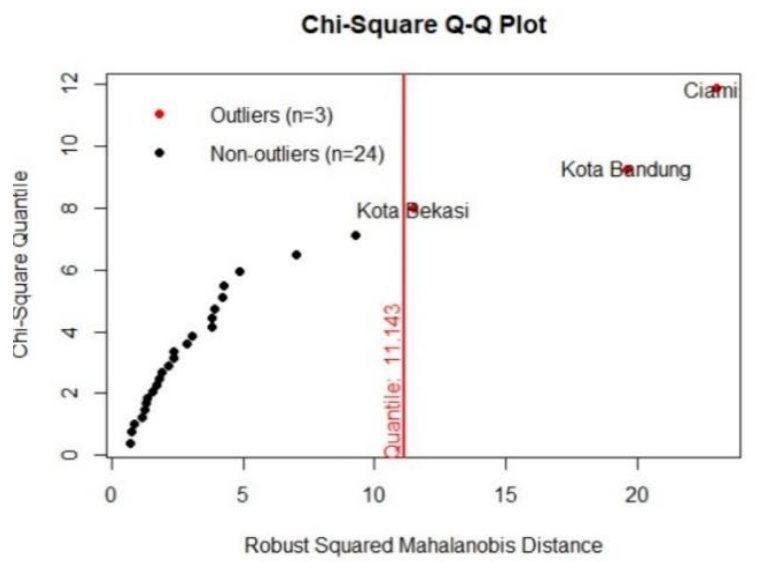

GAMBAR 2. Deteksi Outlier Pada Data

Berdasarkan GAMBAR 2 didapatkan hasil bahwa data IPM Provinsi Jawa Barat tahun 2020 dari $27 \mathrm{kab} / \mathrm{kota}$ terdapat sebanyak 3 wilayah yang outlier, dan data non outlier sebanyak 24 kab/kota. Oleh karena itu, untuk data dengan outlier disarankan menggunakan analisis cluster non hirarki yaitu k-medoids clustering. Selanjutnya dilakukan standarisasi data seperti berikut:

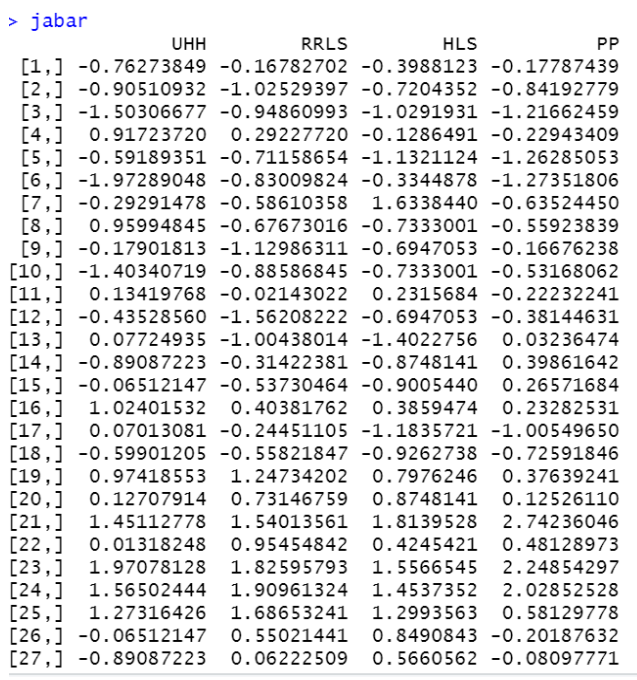

GAMBAR 3. Data Terstandarisasi

Berdasarkan GAMBAR 3 menunjukan hasil data yang sudah distandarisasi. Pada analisis cluster data harus distandarisasi dengan tujuan untuk membuat variabel yang dapat dibandingkan. Standarisasi terdiri dari mengubah variabel sehingga data memiliki rata-rata bernilai 0 serta standar deviasi bernilai 1 . 


\section{Uji Multikolinieritas}

Pengecekan multikolinearitas merupakan asumsi dalam analisis cluster non-hirarki yaitu diharapkan no multikolinearitas atau sebaiknya tidak ada korelasi antar variabel. Pada pengecekan no multikolinearitas ini menggunakan nilai VIF atau nilai dari matriks korelasi dari semua variabel. Berikut merupakan hasil pengujian multikolinieritas.

TABEL 2. Hasil VIF Antar Variabel

\begin{tabular}{cc}
\hline Variabel & VIF \\
\hline AHH & 2.719823 \\
RRLS & 4.917646 \\
HLS & 3.029870 \\
PP & 3.126826 \\
\hline
\end{tabular}

Pada TABEL 2 terlihat bahwa nilai VIF yang diberikan antar variabel-variabel IPM yang meliputi hasil AHH, RRLS, HLS, dan PP dengan nilai VIF nya kurang dari 10 (VIF < 10). Sedangkan ketika nilai VIF menghasilkan angka yang melebihi 10 maka dapat menunjukan bahwa data memiliki multikolinearitas (Eko Supriyadi, Scolastika Mariani, 2017). Dilakukan uji hipotesis berikut:

$\mathrm{H}_{0}$ : No multikolinearitas

$\mathrm{H}_{1}$ : Multikolinearitas

Pada tingkat signifikansi sebesar $\alpha=5 \%$ digunakan Statistik uji berupa nilai VIF. Diperoleh bahwa nilai $V I F$ antar semua variabel kurang dari 10 (VIF < 10). Daerah kritis merupakan daerah penolakan, dimana $\mathrm{H}_{0}$ ditolak jika VIF $>10$. Karena semua nilai VIF <10, maka keputusan yang diperoleh adalah gagal tolak $\mathrm{H}_{0}$. Sehingga diperoleh sebuah kesimpulan yaitu pada tingkat kepercayaan 95\%, diperoleh bahwa data IPM di Provinsi Jawa Barat pada tahun 2020 tidak terdapat korelasi antar semua variabelnya.

\section{Analisis Clustering K-Medoids}

Berikut output hasil metode silhouette dengan menentukan nilai $k$ optimal.

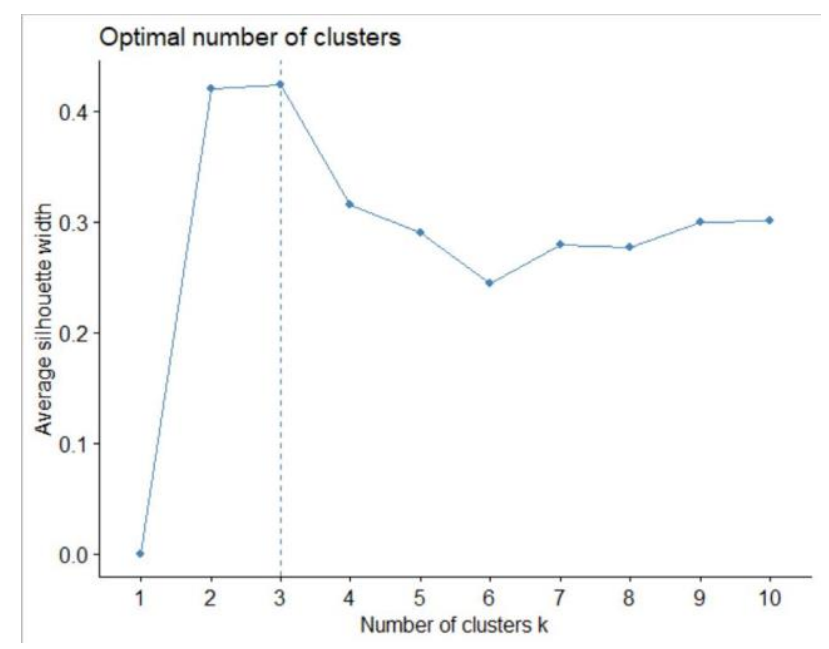

GAMBAR 4. Menentukan Cluster Optimal

Berdasarkan GAMBAR 4 diperoleh hasil pendekatan metode silhouette, dapat dilihat rekomendasi $k$ optimal ketika $k=3$, ditandai dengan tampilan garis vertikal putus-putus yang berada di sumbu $\mathrm{x}$ pada angka 3. Setelah jumlah $k$ ditetapkan, langkah selanjutnya yaitu melakukan proses cluster. Clusterisasi yang dilakukan bertujuan untuk mengelompokkan kabupaten/kota dengan mengelompokkan menjadi 3 kelompok (Tinggi, Sedang, dan Rendah). Berikut hasil cluster IPM Provinsi Jawa Barat. 


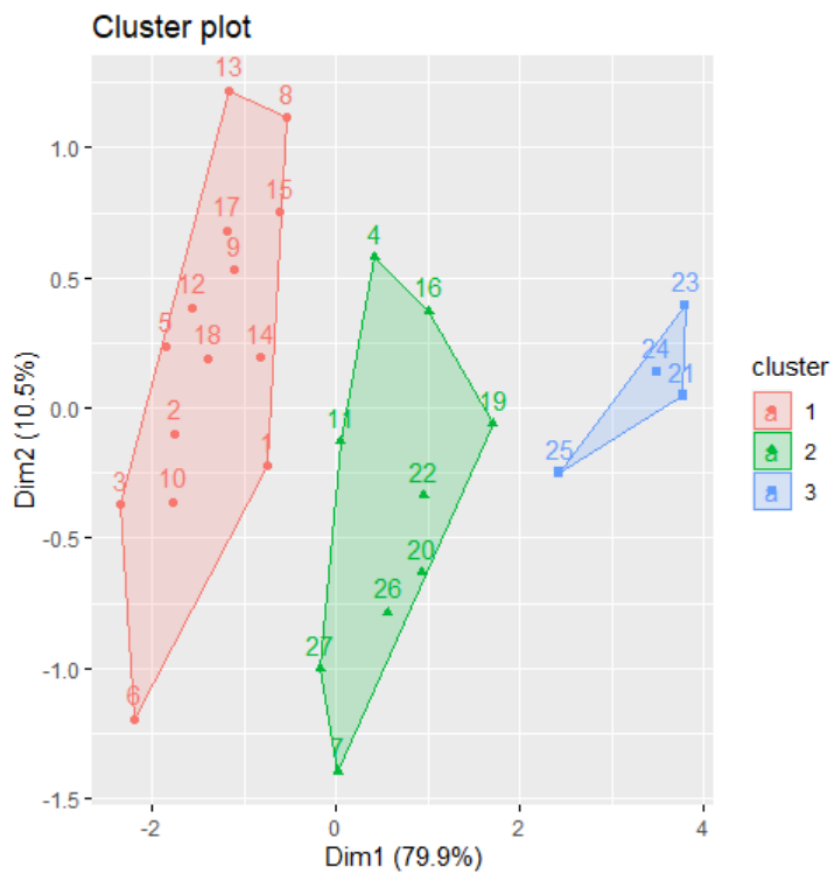

GAMBAR 5. Plot Hasil Cluster

Pada GAMBAR 5 diperoleh plot hasil cluster dengan 3 warna yang berbeda. Warna tersebut menunjukkan hasil cluster dari setiap kab/kota. Adapun cluster 1 ditandai dengan warna merah, cluster 2 warna hijau, dan cluster 3 warna biru. Untuk mempermudah dalam membacanya, berikut pemaparan tabel pengelompokan di wilayah Jawa Barat.

TABEL 3. Hasil Cluster

\begin{tabular}{clc}
\hline Kelompok & \multicolumn{1}{c}{ Kabupaten/Kota } & Jumlah Anggota \\
\hline 1 & $\begin{array}{l}\text { Subang, Bogor, Kuningan, Cirebon, Bandung Barat, } \\
\text { Cianjur, Garut, Karawang, Tasikmalaya, Majalengka, }\end{array}$ & 14 \\
& $\begin{array}{l}\text { Indramayu, Sukabumi, Pangandaran, Purwakarta } \\
\text { Kota Sukabumi, Bandung, Ciamis, Sumedang, Bekasi, } \\
\text { Kota Bogor, Kota Tasikmalaya, Kota Banjar, Kota }\end{array}$ & 9 \\
& $\begin{array}{l}\text { Cirebon } \\
\text { Kota Bandung, Kota Cimahi, Kota Bekasi, Kota } \\
\text { Depok }\end{array}$ & 4 \\
\hline
\end{tabular}

Pada TABEL 3 merupakan hasil pengelompokan IPM Provinsi Jawa Barat menjadi 3 kelompok yang memiliki jumlah anggota berbeda-beda pada setiap cluster. Kelompok 1 memiliki anggota sebanyak 14 kabupaten, kelompok 2 memiliki anggota sebanyak yaitu 9 kabupaten/kota. dan kelompok 3 memiliki anggota sebanyak 4 kota.

\section{Profilisasi}

Setelah mengetahui jumlah dan anggota cluster, selanjutnya melakukan profilisasi untuk mengetahui karakteristik atau ciri khas dari setiap kelompok. Dalam melakukan profilisasi ini digunakan hasil rata-rata variabel pada setiap cluster. 


\section{Indikator IPM Jawa Barat}

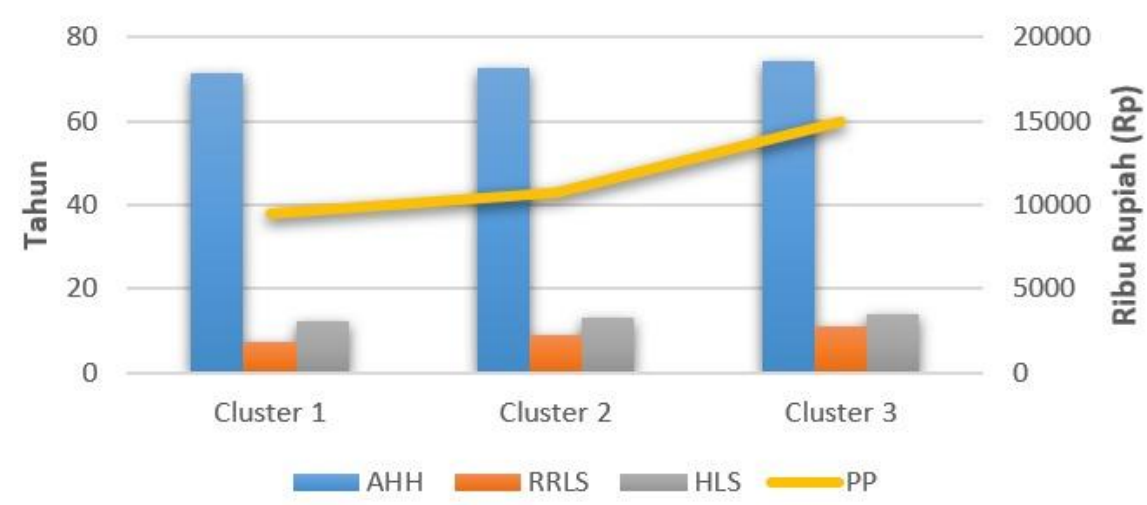

GAMBAR 6. Bar Chart Indikator IPM Jawa Barat

Berdasarkan GAMBAR 6, keterangan angka di samping kiri menunjukan besaran indikator dengan satuan tahun untuk AHH, RRLS, dan HLS. Sedangkan keterangan angka di samping kanan menunjukan besaran indikator dengan satuan ribu rupiah untuk PP. Keterangan tersebut dapat diinterpretasikan dengan hasil sebagai berikut:

a. Cluster 1 dengan grafik warna biru merupakan kelompok kabupaten dengan AHH, RRLS, HLS, dan PP yang rendah.

b. Cluster 2 dengan grafik warna oren merupakan kelompok kabupaten/kota dengan AHH, RRLS, HLS, dan PP yang sedang.

c. Cluster 3 dengan grafik warna abu-abu merupakan kelompok kota dengan AHH, RRLS, HLS, dan PP yang tinggi.

\section{KESIMPULAN}

Penelitian ini menunjukkan bahwa hasil analisis deskriptif yaitu pada indikator IPM berdasarkan kabupaten atau kota di Provinsi Jawa Barat memiliki nilai tertinggi pada indikator AHH sebesar 75.01, RRLS sebesar 11.280, HLS sebesar 14.20, dan PP sebesar 16887. Sedangkan terendah pada indikator AHH sebesar 69.47, RRLS 6.300, HLS 11.70, dan PP 7852. Pengelompokan dengan menggunakan metode $K$-medoids clustering diperoleh hasil cluster 1 sebanyak 14 anggota sebagai kabupaten/kota dengan jumlah IPM yang rendah. Cluster 2 sebanyak 9 anggota sebagai kabupaten/kota dengan jumlah IPM yang sedang. Sedangkan cluster 3 sebanyak 4 anggota sebagai kabupaten/kota dengan jumlah IPM yang tinggi.

\section{REFERENSI}

Asroni, \& Adrian, R. (2015). Penerapan Metode K-Means Untuk Clustering Mahasiswa Berdasarkan Nilai Akademik Dengan Weka Interface Studi Kasus Pada Jurusan Teknik Informatika UMM Magelang. Jurnal Ilmiah Semesta Teknika, 18(1), 76-82.

BPS. (2021). Indeks Pembangunan Manusia (IPM) Provinsi Jawa Barat pada Tahun 2020 Mencapai 72,09. Jakarta: Badan Pusat Statistik.

Dewi, N. L. S., \& Sutrisna, I. K. (2014). Pengaruh Komponen Indeks Pembangunan Manusia Terhadap Pertumbuhan Ekonomi Provinsi Bali. E-Jurnal EP Unud, 3, 106-114.

Dinas Perhubungan. (2013). INDIKATOR VARIABEL DALAM PENGUKURAN INDEKS PEMBANGUNAN MANUSIA (IPM). Retrieved from http://dishub.jabarprov.go.id/artikel/view/298.html 
Eko Supriyadi, Scolastika Mariani, S. (2017). Perbandingan Metode Partial Least Square (Pls) Dan Principal Component Regression (Pcr) Untuk Mengatasi Multikolinearitas Pada Model Regresi Linear Berganda. Unnes Journal of Mathematics, 6(2), 117-128. https://doi.org/10.15294/ujm.v6i2.11819

Han, J., \& Kamber, M. (2006). Data Mining Concepts and Techniques Second. Edition. San Francisco: Morgan Kaufmann.

Riyanto, B. (2019). Penerapan Algoritma K-Medoids Clustering Untuk Pengelompokkan Penyebaran Diare Di Kota Medan (Studi Kasus: Kantor Dinas Kesehatan Kota Medan). KOMIK (Konferensi Nasional Teknologi Informasi Dan Komputer), 3(1), 562-568. https://doi.org/10.30865/komik.v3i1.1659

Supranto, J. (2004). Analisis Multivariat, Arti dan Interpretasi. Jakarta: PT. Rineka Cipta.

Sutjipto, H. (2006). Sinergitas Pembangunan Daerah dalam Meningkatkan IPM di Jawa Barat. XXII(4), 479-495.

UNDP. (2001). Human development report 2001: Making new technologies work for human development. In Human Development Report 2001. New York: Oxford University Press. Retrieved from

http://hdr.undp.org/sites/default/files/reports/262/hdr_2001_en.pdf\%0Ahttp://dspace.cigilibrary.org /jspui/handle/123456789/20137

Widodo, E., Mashita, S. N., \& Prasetyowati, Y. G. (2020). Perbandingan Metode Average Linkage, Complete Linkage, dan Ward'S pada Pengelompokan Kabupaten/Kota di Provinsi Jawa Tengah Berdasarkan Indikator Indeks Pembangunan Manusia. Faktor Exacta, 13(2), 81-87. https://doi.org/10.30998/faktorexacta.v13i2.6581

Wira, B., Budianto, A. E., \& Wiguna, A. S. (2019). Implementasi Metode K-Medoids Clustering untuk Mengetahui Pola Pemilihan Program Studi. Jurnal Terapan Sains \& Teknologi, 1(3), 54-69. 